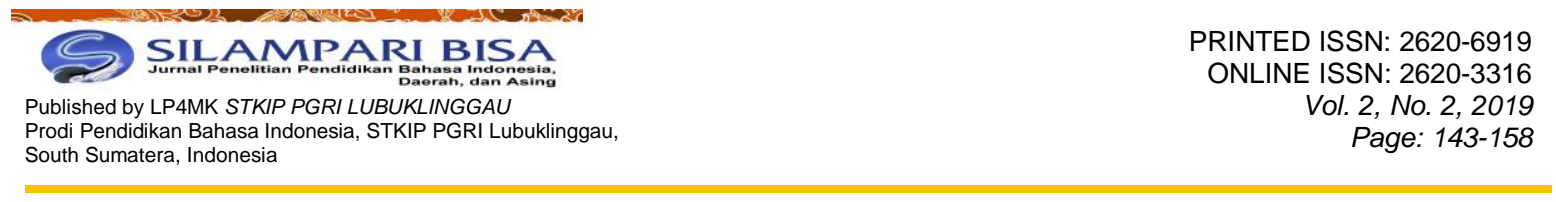

\title{
HUBUNGAN MODEL NON DIRECTIVE TEACHING DENGAN MOTIVASI BELAJAR BAHASA ARAB SISWA SMK MUHAMMADIYAH PRAMBANAN
}

\author{
Nurlaila \\ Program Studi Pendidikan Bahasa Arab, UIN Sunan Kalijaga Yogyakarta \\ Jln. Laksda Adisucipto, Papringan, Caturtunggal, Kec. Depok, Kabupaten Sleman, \\ Daerah Istimewa Yogyakarta 55281, Indonesia \\ Email: lailrifai55@gmail.com
}

\begin{abstract}
Abstrak
Penelitian ini bertujuan untuk mengetahui hubungan penerapan model non directive teaching terhadap motivasi belajar bahasa Arab siswa SMK Muhammadiyah Prambanan. Penelitian ini menggunakan metode kuantitatif dengan desain korelasi. Instrumen penelitian yang digunakan adalah wawancara, observasi, dokumentasi, dan kuesioner yang disebarkan kepada 104 siswa dari jumlah seluruh populasi sebesar 245 siswa kelas XI yang selanjutnya dilakukan uji validitas, reliabilitas, normalitas, dan linearitas. Untuk mengetahui besar nilai signifikansi hubungan dan pengaruh model non directive teaching dengan motivasi belajar dilakukan uji korelasi dan uji regresi. Dari perhitungan menggunakan rumus koefisien korelasi product moment, diketahui terdapat hubungan yang positif dan sangat signifikan antara penerapan model non directive teaching dengan motivasi belajar bahasa Arab siswa kelas XI di SMK Muhmmadiyah Prambanan sebesar rxy 0,428 dan sumbangan efektif penerapan model non directive teaching terhadap motivasi belajar bahasa Arab hanya sebesar $18,3 \%$ ( $R$ square 0,183 ) sedangkan sebesar $71,3 \%$ motivasi belajar bahasa Arab siswa dipengaruhi oleh faktor lain. Oleh karena itu, untuk perbaikan kualitas pembelajaran, penerapan model non directive teaching perlu dikemas dengan berbagai metode pembelajaran yang mendukung, baik untuk proses non directive counseling dan maupun tujuan pembelajaran yang diinginkan. Hal ini dikarenakan motivasi belajar siswa adalah variabel yang dipengaruhi oleh berbagai faktor.
\end{abstract}

Kata kunci: model non directive teaching, motivasi belajar, bahasa Arab

\section{THE RELATIONSHIP OF THE NON DIRECTIVE TEACHING MODEL WITH ARABIC LEARNING MOTIVATION OF VOCATIONAL SCHOOL OF MUHAMMADIYAH PRAMBANAN}

\begin{abstract}
This study aims to determine the relationship of the application of the nondirective teaching model to the Arabic learning motivation of SMK Muhammadiyah Prambanan students. This research uses quantitative methods with correlation design. The research instrument used was interviews, observation, documentation, and questionnaires distributed to 104 students from a total population of 245 class $\mathrm{XI}$ students, which then tested the validity, reliability, normality, and linearity. To find out the significance of the relationship and the effect of the nondirective teaching model with learning motivation, a correlation test, and a regression test was performed. From the calculation using the product-moment correlation coefficient formula, it is known that there is a positive and very significant relationship between the application of the nondirective teaching model with the motivation to learn Arabic class XI students at SMK Muhmmadiyah
\end{abstract}


Prambanan by rxy 0.428 and the effective contribution of the application of the nondirective teaching model to language learning motivation Arabic is only $18.3 \%$ ( $R$ square 0.183 ) while $71.3 \%$ of students' Arabic learning motivation is influenced by other factors. Therefore, to improve the quality of learning, the application of the nondirective teaching model needs to be packaged with a variety of supportive learning methods, both for the nondirective counseling process and as well as the desired learning objectives. This is because student motivation is a variable that is influenced by various factors.

Keywords: nondirective teaching model, learning motivation, Arabic language

\section{A. Pendahuluan}

Belajar dimaknai sebagai proses perubahan tingkah laku yang relatif menetap sebagai akibat dari proses interaksi individu dengan lingkungannya. Perubahan tingkah laku ini meliputi aspek kognitif, afektif, dan psikomotorik. Jadi belajar tidak hanya sekedar menghafal dan menerima materi pelajaran melainkan suatu proses mental yang terjadi dalam diri individu. Dalam proses belajar, motivasi sangat diperlukan, sebab seseorang yang tidak mempunyai motivasi dalam belajar tidak akan mungkin melakukan aktivitas belajar. Oleh karena itu, motivasi dan belajar adalah dua hal yang saling mempengaruhi (Latipah, 2012:160).

Sebagaimana motivasi dan belajar saling mempengaruhi, hal ini pun yang terjadi dalam pembelajaran bahasa Arab. Sebagai sebuah bahasa asing, bahasa Arab memiliki perbedaan dengan bahasa Indonesia yang berpotensi menimbulkan masalah bagi siswa Indonesia dalam mempelajari bahasa Arab (Asyrofi, 2010:60). Penyataan tersebut selaras dengan realita yang terjadi pada siswa SMK Muhammadiyah Prambanan, yang mana masih banyak siswa yang merasa kesulitan belajar bahasa Arab. SMK Muhammadiyah Prambanan merupakan sekolah berbasis kejuruan, yang mana mayoritas siswanya merupakan remaja laki-laki. Selain masalah linguistik (fonologi, morfologi, sintaksis, dan semantik) yang merupakan problem utama yang dihadapi oleh siswa, di sisi lain berdasarkan background keilmuan yang diminati siswa adalah keilmuan praktis (empiris) sehingga kecenderungan siswa untuk mempelajari ilmu-ilmu normatik-teoritik seperti bahasa Arab masih sangat minim sehingga motivasi dan minat siswa dalam belajar bahasa Arab sangatlah kurang. Oleh 
karena itu, perlu adanya tindakan khusus untuk meningkatkan motivasi siswa dalam belajar bahasa Arab.

Guru mata pelajaran bahasa Arab di SMK Muhammadiyah Prambanan secara khusus menerapkan model pembelajaran dengan metode pendekatan personal Non Directive Teaching. Model non directive teaching merupakan salah satu model pengajaran personal yang didasarkan pada teori konseling seorang tokoh psikolog humanis Carl Rogers dengan judul Client Centered Theory yang sering juga disebut sebagai teori non directive atau perpusat pada pribadi (personal). Teori Rogers tentang terapi diperluas ke dalam dunia pendidikan sebagai sebuah model pembelajaran (pengajaran). Non directive teaching menitik beratkan pada membangun hubungan positif, Rogers dengan pandangan humanis meyakini bahwa hubungan positif antar sesama manusia memudahkan individu untuk tumbuh. Oleh sebab itu, instruksi-intruksi dalam pembelajaran seharusnya didasarkan pada konsep-konsep mengenai hubungan sesama manusia dibandingkan dengan konsep-konsep dalam materi pelajaran (Joyce, dkk., 2011:373). Pentingnya hubungan positif dalam pembelajaran diperkuat oleh pendapat Dowson dan Mclnerney sebagaimana yang dikutip oleh Ormrod (2008:75) bahwa hubungan sosial cenderung menjadi salah satu prioritas tertinggi siswa. Siswa lebih mungkin termotivasi secara akademik dan sukses dan lebih mungkin tetap berada di sekolah, alih-alih putus sekolah ketika mereka percaya bahwa teman-teman dan guru mereka menyukai serta menghargai.

Pandangan di atas menjelaskan bahwa hubungan positif yang terjalin selama pembelajaran akan berdampak terhadap motivasi siswa. Keduanya bisa saling berkaitan dikarenakan adanya aspek emosi yang terlibat selama pembelajaran. Filasafat non directive intervence memandang emosi sebagai situasi pengalaman holistik yang dijalani melibatkan 'keseluruhan' keberadaan seseorang, perasaan sangat tersentuh, dan mendalam. Selama pengalaman holistik itu berlangsung, orang belajar dan mengembangkan dirinya, memandang pengalaman sebagai hal yang benar-benar relevan bagi mereka dan menghasilkan hubungan keterikatan yang sangat penting untuk belajar (Georgopoulos \& Vouyoukasi, 2018:128). Dengan begitu belajar, motivasi, emosi, dan keinginan saling mempengaruhi dan tugas guru adalah menyiapkan 
lingkungan agar aspek-aspek ini tidak terabaikan selama pembelajaran. Sebagaimana yang dikatakan Lobort (dalam Georgopoulos \& Vouyoukasi, 2018:128) bahwa belajar adalah respons terhadap stimulus lingkungan dengan motivasi internal individu dan keinginan yang tidak terpisahkan yang terkait dengannya.

Makna dari non directive teaching adalah tanpa menggurui. Dari sikap non directive teaching peran guru adalah sebagai fasilitator yang menjelaskan relasi konseling (bimbingan) pada para siswa serta mengarahkan perkembangan dan pertumbuhan mereka. Guru memiliki peran penting dalam menciptakan pembelajaran yang efektif dan efisien salah satunya dengan memilih model pembelajaran yang tepat (Effendi \& Melia, 2019:46). Hal ini sesuai juga dengan pendapat Noermanzah (2015:274) bahwa tugas guru menjadi fasilitator yang mampu menciptakan pembelajaran yang menarik, kreatif, dan inovatif salah satunya melalui penerapan model non directive teaching. Akan tetapi, sebuah model pembelajaran yang diterapkan harus bener-benar direncanakan dengan baik dan dibantu oleh media pembelajaran yang komunikatif, begitpun dalam penerapan model non directive teaching (Noermanzah, dkk., 2018).

Kelebihan model non directive teaching yaitu menciptakan sebuah lingkungan yang sehat sehingga memudah siswa dan guru bekerja sama dalam proses pembelajaran. Model ini juga memudahkan siswa untuk saling berbagi gagasan secara terbuka serta membangun komunikasi yang sehat (Joyce, dkk., 2011: 373). Teknik utama dalam mengaplikasikan model non directive teaching adalah dengan non directive interview atau wawancara tanpa menggurui antara guru dan siswa. Selama wawancara guru berperan sebagai kolaborator dalam proses penggalian jati diri dan pemecahan masalah siswa, inilah yang dimaksud dengan tanpa menggurui (non-directive). Secara singkat model pembelajaran ini dapat membantu siswa memperkuat persepsi terhadap dirinya dengan mengevaluasi kemajuan dan perkembangan dirinya (Uno, 2011:18-19).

Berdasarkan hal ini, penerapan model non directive teaching dalam pembelajaran Bahasa Arab oleh guru bahasa Arab dapat diasumsikan sebagai langkah alternatif dalam menumbuhkan dan mendorong siswa untuk aktif belajar 
dan mengatasi berbagai masalah pembelajaran yang mereka hadapi. Dengan melakukan komunikasi konseling dan pendekatan dengan siswa terkait kesulitankesulitan belajar dan menciptakan suasana interaksi yang hangat antara guru dengan siswa. Dengan menerapkan model non directive teaching ini akan dihasilkan pembelajaran yang kondisional sesuai keadaan dan kondisi siswa dengan mempertimbangkan kebutuhannya. Dengan melihat kondisi siswa demikian, pembelajaran bahasa Arab tidak harus menetapkan standar idealis sebagaimana yang dirumuskan dalam kurikulum, namun cukup dengan membuat siswa mau belajar adalah pencapaian yang positif selama pembelajaran.

Rogers mengelompokkan tahap non directive teaching ke dalam lima tahap (Uno, 2011:19-20): tahap pertama, membantu siswa menemukan inti permasalahan yang dihadapinya. Tahap kedua, guru mendorong (memancing siswa) agar dapat mengekspresikan perasaannya, baik positif maupun negatif. Tahap ketiga, siswa secara bertahap mengembangkan pemahaman (kesadaran) akan dirinya. Tahap keempat, siswa melaporkan tindakan (berupa alternatifalternatif) pemecahan masalah yang telah diambilnya pada tahap ketiga. Secara umum dapat disimpulkan bahwa pembelajaran model akan berhasil dan memberikan dampak positif hanya apabila didasarkan pada kebutuhan (needs) atau apa yang dibutuhkan oleh siswa, bukan apa yang harus dipelajari siswa. Secara operasional definisi penerapan non directive teaching dalam penelitian ini adalah pandangan, penafsiran, pendapat, dan pemberian makna yang dilakukan oleh siswa terhadap penerapan model non directive teaching yang dilakukan oleh guru dalam pembelajaran yang diukur melalui empat fase (tahapan) yaitu menjelaskan keadaan yang membutuhkan pertolongan, menelusuri masalah, mengembangkan wawasan, merencanakan, dan membuat keputusan. Dari keempat aspek tersebut maka dapat diopreasionalkan dalam indikator berikut. Berikuit klasifikasi aspek dan inidkator model non directive teaching. 
Tabel 1. Aspek dan Indikator Non Directive Teaching

\begin{tabular}{|c|c|}
\hline Aspek & Indikator \\
\hline $\begin{array}{l}\text { Keadaan yang membutuhkan } \\
\text { pertolongan }\end{array}$ & $\begin{array}{l}\text { 1. Guru mendorong siswa untuk mengungkapkan } \\
\text { perasaan dengan bebas. } \\
\text { 2. Siswa dapat leluasa mengungkapkan perasaannya. }\end{array}$ \\
\hline Menelusuri masalah & $\begin{array}{l}\text { 3. Siswa didorong menjabarkan masalah. } \\
\text { 4. Guru menerima dan mengapresiasi perasaan dan } \\
\text { permasalahan yang diutarakan siswa. }\end{array}$ \\
\hline Mengembangkan wawasan & $\begin{array}{l}\text { 5. Siswa mendiskusikan masalah. } \\
\text { 6. Guru menyemangati siswa. }\end{array}$ \\
\hline $\begin{array}{l}\text { Merencanakan dan membuat } \\
\text { keputusan }\end{array}$ & $\begin{array}{l}\text { 7. Siswa merencanakan urutan dalam proses } \\
\text { pengambilan keputusan. } \\
\text { 8. Siswa mendapat wawasan lebih mendalam dan } \\
\text { mengembangkan tindakan yang positif. }\end{array}$ \\
\hline
\end{tabular}

Kaitan non directive teaching dengan motivasi belajar dapat dijelaskan dalam teori motivasi Rogers dan teori motivasi Maslow, bahwa pada dasarnya semua manusia hakikatnya selalu ingin melakukan aktualisasi diri berprestasi dan menunjukkan kemampuan-kemampuan diri yang positif. Namun, aktualisasi diri ini hanya akan dilakukan jika kebutuhan-kebutuhan pokonya seorang individu sudah terpenuhi. Rogers (dalam Schunk, dkk., 2012: 53) mengemukakan sebuah istilah pengalaman tentang diri (self-experience) yakni berbagai interaksi individu dengan lingkungannya dan individu-individu yang signifikan baginya. Adanya self experience ini menciptakan kebutuhan perhatian positif (positive regard) yang mengacu pada perasaan-perasaan seperti kehormatan, kesukaan, kehangatan, simpati, dan penerimaan. Kebutuhan perhatian positif ini memiliki efek resiprokal (timbal balik), ketika individu mempersepsikan dirinya memenuhi kebutuhan perhatian positif individu lain, individu tersebut mengalami pemenuhan atas kebutuhan perhatian positif dirinya (Schunk, dkk., 2012: 53).

Sejalan dengan hal tersebut, Maslow (dalam Schunk, dkk., 2012:262) mengemukkakan lima tingkat kebutuhan; 1) kebutuhan fisiologi, 2) kebutuhan rasa aman, 3) kebutuhan kasih sayang, 4) kebutuhan penghormatan, dan 5) kebutuhan aktualisasi diri. Kebutuhan yang paling tinggi (pertumbuhan) yakni aktualisasi diri adalah paling penting bagi perkembangan kepribadian. Sedangkan empat kebutuhan di bawahnya merupakan kebutuhan defisiensi atau kebutuhan 
yang pokok. Jika kedua kebutuhan yang berbeda saling bertentangan maka kebutuhan yang lebih rendah akan mendominasi. Sama halnya dalam pemenuhan kebutuhan tersebut, lingkungan juga ikut berperan. Lingkungan menyediakan berbagai kesempatan untuk pemenuhan kebutuhan. Jika lingkungan tidak memungkinkan kebutuhan terpenuhi, pertumbuhan dan perkembangan tidak akan terjadi pada tingkat optimal. Oleh karena itu, pendidikan dan pembelajaran sudah semestinya menciptakan pemenuhan kebutuhan penerimaan diri siswa, kondisi ini akan berdampak pada aktivitas pembelajaran terciptanya adanya hubungan yang baik, penerimaan dan penghargaan yang terjalin antara guru dan siswa.

Motivasi berasal dari kata latin movere (menggerakkan). Dalam beberapa padangan teori, motivasi dipandang sebagai kekuatan batiniah (inner force), sifat yang bertahan lama, respons perilaku terhadap stimulus, dan berbagai kumpulan keyakinan dan afek (Schunk, dkk., 2012:8). Motivasi adalah suatu proses diinisiasikannya dan dipertahankannya aktivitas yang diarahkan pada pencapaian tujuan. Menurut Schunk (2012:7-8) pengertian ini mengandung empat kata kunci, yaitu 1) proses, motivasi merupakan sebuah proses ketimbang sebuah hasil. Sebagai sebuah proses motivasi disimpulkan dari berbagai tindakan (pilihan tugas, usaha, kegigihan) dan verbalisasi. 2) Tujuan, motivasi menyangkut berbagai tujuan yang memberikan daya penggerak dan arah bagi tindakan. 3) Aktivitas, motivasi menuntut adanya aktivitas fisik maupun mental. Aktivitas fisik memerlukan usaha, kegigihan dan tindakan lainnya yang diamati. Aktivitas mental mencakup berbagai tindakan kognitif seperti perencanaan, penghafalan, pengorganisasian dan lain-lain. 4) Diinisiakan dan dipertahankan, pencapaian sebuah tujuan merupakan sebuah proses penting dan sulit, proses ini melibatkan pembentukan sebuah komitmen. Oleh karena itu, proses-proses motivasi sangatlah penting dalam mempertahankan tindakan.

Berdasarkan yang dikemukakan oleh para ahli di atas maka dapat disimpulkan bahwa motivasi merupakan pendorong atau penggerak individu untuk melakukan sesuatu, atau lebih jelasnya motivasi adalah sebuah proses dipertahankannya aktivitas oleh individu untuk mencapai tujuan tertentu (motivasi berarah kepada tujuan). Sedangkan motivasi belajar adalah keseluruhan daya 
penggerak psikis di dalam diri siswa yang menimbulkan kegiatan belajar, menjamin kelangsungan kegiatan belajar dan memberikan arah pada kegiatan belajar itu demi mencapai suatu tujuan. Untuk memudahkan pengukuran tingkat motivasi siswa, perlu didefinisikan secara operasional, motivasi belajar siswa adalah keseluruhan daya penggerak psikis di dalam diri siswa yang menimbulkan kegiatan belajar bahasa Arab yang menjamin kelangsungan kegiatan belajar bahasa Arab dan memberikan arah pada kegiatan belajar bahasa Arab untuk mencapai suatu tujuan. Dari definisi tersebut maka dapat disimpulkan empat aspek yang terkandung dalam motivasi belajar yaitu adanya pengalaman, harapan, usaha, serta aktivitas dan adanya komitmen, yang kemudian dapat dioperasionalkan dalam indikator motivasi belajar bahasa Arab berikut.

Tabel 2. Aspek dan Indikator Motivasi

\begin{tabular}{c|ll}
\hline Aspek & \multicolumn{2}{c}{ Indikator } \\
\hline Pengalaman & 1. $\begin{array}{l}\text { Mengalami tekanan dari lingkungan yang mendorong untuk keluar } \\
\text { dari tekanan tersebut. }\end{array}$ \\
& 2. Adanya hal yang menarik dari lingkungan yang menjawab \\
kebutuhan dalam belajar bahasa Arab.
\end{tabular}

Hasil penelitian yang relevan pernah dilakukan oleh Ghofur (2009), tentang pengaruh pembelajaran non directive teaching terhadap keberhasilan belajar siswa kelas VII pada Mata Pelajaran Akidah Akhlak di MTs Al-Bukhary Angger Sreseh Sampang. Hasil penelitian ini menunjukkan bahwa terdapat pengaruh penerapan model non directive teaching terhadap keberhasilan belajar siswa sebesar $R$ square 0,480. Meskipun penelitian tersebut meneliti pengaruh non directive teaching terhadap variabel keberhasilan belajar, sedang penelitian ini menguji variabel motivasi siswa. Namun, dari penelitian tersebut memberikan gambaran bahwa penerapan non directive teaching memberikan dampak pada keberhasilan belajar siswa. Perlu diketahui hubungan belajar dan motivasi sangat erat kaitannya. Belajar hanya akan berhasil jika siswa terdorong untuk 
melakukannya, tanpa ada motivasi/dorongan, individu tidak akan melakukan aktivitas apapun termasuk belajar. Selain itu, penelitian yang dilakukan oleh Georgopoulos \& Vouyoukasi (2018), dengan judul The Effect of the NonDirectuve Interventation on Preservice Kindergarden Teachers' Self-Esteem, SelfEfficacy and Personal Growth. Hasil penelitian ini menunjukkan bahwa pengalaman holistik yang dicipatakan melalui teknik non directive inteventation dalam pembelajaran memberikan dampak dalam mengembangkan efikasi diri, harga diri, dan pertumbuhan pribadi. Prinsip self-directivity memberi siswa kesempatan untuk mengekspresikan diri mereka sendiri, membantu mereka mengungkapkan subyektivitas mereka. Elemen pribadi/subjektif yang terlibat dalam pendidikan pengalaman, yaitu dengan mempertimbangkan persepsi dan preferensi siswa, dengan begitu akan menciptakan motivasi intrinsik yang kuat bagi mereka untuk belajar.

Dari beberapa penelitian relevan tersebut menunjukkan bahwa hubungan penerapan model non directive teaching terhadap motivasi belajar bahasa Arab siswa SMK Muhammadiyah Prambanan belum pernah diteliti. Untuk itu, pentingnya dilakukan penelitian sehingga diharapkan apabila terbukti adanya hubungan di antara variabel tersebut maka model non directive teaching dapat digunakan sebagai salah satu solusi oleh guru bahasa dalam meningkatkan motivasi belajar.

\section{B. Metode Penelitian}

Penelitian ini menggunakan metode penelitian korelasional. Populasi penelitian ini adalah seluruh siswa kelas XI SMK Muhammadiyah Prambanan sebesar 245 dengan diperoleh sampel mengunakan teknik random sampling sebesar 104 siswa dikarenakan secara umum seluruh populasi memiliki karakteristik yang sama untuk dijadikan sampel, oleh karena itu sampel diambil secara acak.

Data dalam penelitian diperoleh melalui kuesioner (angket) yang disebarkan kepada responden yang telah ditentukan. Selanjutnya data tersebut harus melalui uji prasyarat data berupa uji validitas, reliabilitas, normalitas, dan linearitas, sebelum akhirnya dilakukan perhiitungan korelasi product moment 
untuk mengetahui hubungan non directive teaching dengan motivasi belajar. Selain itu, untuk mengetahui keberartian hubungan tersebut dilakukan perhitungan regresi sederhana untuk mengukiur seberapa besar pengaruh variabel $\mathrm{X}$ (non directive teaching) terhdap $\mathrm{Y}$ (motivasi belajar).

\section{Hasil Penelitian dan Pembahasan}

\section{Hasil Penelitian}

Uji prasyarat data dilakukan terhadap seluruh item (butir soal) yang terdapat pada masing-masing variabel, sebanyak 46 item soal penerapan model non directive teaching sedangkan jumlah item instrumen motivasi belajar bahasa Arab siswa sebanyak 53 item. Pertama, uji validitas dilakukan dengan mematok nilai $r$ tabelnya dalam taraf signifikan alpha $5 \%(0,05)$, jika nilai $r$ hitung lebih rendah dari pada $r$ tabel maka item (butir soal) variabel dinyatakan gugur. Kedua, uji reliabilitas terhadap masing-masing item variabel, jika nilai cronbach alpha lebih besar dari 0.06 maka instrumen dinyatakan reliabel. Ketiga, uji normalitas dilakukan untuk mengetahui penyebaran data peneltian berdistribusi secara normal dalam sebuah populasi, jika nilai sig. (p) lebih besar dari 0.05 maka data bedistribusi normal. Keempat, uji linearitas untuk mengetahui hubungan variabel independen $(X)$ dan variabel dependen $(Y)$ bersifat linear, jika nilai $p$ ( $F$ linearity) lebih kecil dari 0.05 , dan nilai $p$ (deviation from lineariti) lebih besar dari 0.05 maka hubungan variabel dikatakan linear.

Tabel 3. Hasil Uji Prasyarat Kuesioner

\begin{tabular}{|c|c|c|c|}
\hline Uji & Non Directive Teaching & Motivasi Belajar & Status \\
\hline \multirow{3}{*}{ Validitas } & $(N=46)$ & $(\mathrm{N}=53)$ & \multirow{3}{*}{ Valid } \\
\hline & Gugur & Gugur & \\
\hline & 42 item & 43 item & \\
\hline Reliabilitas & $\begin{array}{c}\alpha=0,939 \text { hitung }>0,06 \\
\text { tabel }\end{array}$ & $\begin{array}{c}\alpha=0,926 \text { hitung }>0,06 \\
\text { tabel }\end{array}$ & Reliabel \\
\hline Normalitas & $0.181>0.05$ & $0.230>0,05$ & Normal \\
\hline Linearitas & $\begin{array}{l}\text { Linearity } \\
\text { Deviation from lit }\end{array}$ & $\begin{array}{r}:: 0,000<0.05 \\
\text { arity }: 0,101>0.05\end{array}$ & Linear \\
\hline
\end{tabular}

Silampari Bisa: Jurnal Penelitian Pendidikan Bahasa Indonesia, Daerah, dan Asing Vol. 2, No. 2, 2019 
Bedasarkan hasil uji prasyarat data di atas, maka dapat disimpulkan bahwa intrumen kuesioner dapat digunakan untuk mengukur penerapan model non directive teaching dan motivasi belajar bahasa Arab siswa kelas XI SMK Muhammadiyah Prambanan. Selanjutnya, dilakukan uji hipotesis hubungan penerapan model non directive teaching dengan motivasi belajar bahasa Arab siswa dianalisis menggunakan korelasi sederhana dengan menggunakan rumus product moment. Dari hasil analisis perhitungan menggunakan rumus koefisien korelasi pearson terdapat pengaruh dan korelasi positif model non directive teaching dengan motivasi belajar bahasa Arab siswa, yaitu sebesar $r=0.428$. Besar angka korelasi 0,428 menunjukkan korelasi (hubungan) yang sedang karena berada pada kisaran 0,40 - 0,70. Interpretasi korelasi yang sedang ini berdasarkan kriteria interpretasi angka indeks korelasi product moment (rxy) berikut.

Tabel 4. Interpretasi Koefisien Korelasi

\begin{tabular}{cc}
\hline Besar "r" Product Moment & Penafsiran Korelasi \\
\hline $0,00-0,20$ & Sangat Tinggi \\
$0,20-0,40$ & Tinggi \\
$\mathbf{0 , 4 0}-\mathbf{0 , 7 0}$ & Sedang \\
$0,70-0,90$ & Rendah \\
$0,90-0,00$ & Sangat Rendah \\
\hline & (Sumber : Sudijono, 2012:9)
\end{tabular}

Arah korelasi bisa positif maupun negatif, dengan nilai Rxy berkisar -1 sampai +1 . Indeks korelasi pada penelitian ini sebesar 0,428 (bernilai positif) dengan signifikansi $p=0,000$, nilai positif tersebut menujukkan arah korelasi yang positif dan sangat signifikan antara variabel model non directive teaching dengan motivasi belajar bahasa Arab siswa. Hal ini berarti, baik penerapan model non directive teaching maka semakin tinggi pula motivasi belajar bahasa Arab siswa dan sebaliknya semakin rendah/lemah penerapan model non directive teaching maka semakin rendah pula motivasi belajar bahasa Arab siswa.

Selanjutnya, untuk mengetahui keberartian hubungan kedua variabel tersebut perlu diketahui pengaruhnya. Besar pengaruh model non directive teaching dengan motivasi belajar bahasa belajar siswa dihitung menggunakan $R$ square (koefisien determinasi), koefisien determinasi diperoleh dari penguadratan 
dari koefisien korelasi $(R) 0,428 \times 0,428=0,183$. Atau dapat ditulis dalam perhitungan berikut:

$$
\begin{aligned}
& R=r^{2} \times 100 \% \\
& =(0.428)^{2} \times 100 \% \\
& =18.3 \%=0,183
\end{aligned}
$$

Indeks determinasi di atas menunjukkan persentase yang menyumbangkan pengaruh variabel $X$ terhadap $Y$. Jadi dapat disimpulkan bahwa $R 2=0,183$ mengandung pengertian bahwa sebesar 18,3 \% sumbangan penerapan model non directive teaching dalam mempengaruhi motivasi belajar bahasa Arab siswa, sedangkan sisanya sebesar $81,7 \%$ dipengaruhi oleh faktor lain.

Dari hasil analisis perhitungan menggunakan rumus koefisien korelasi pearson ada pengaruh korelasi positif antara model non directive teaching terhadap motivasi belajar bahasa Arab, yaitu sebesar $r=0.428$ yang termasuk kategori sedang $(0,40-0,70)$. Maka, berdasarkan hasil pengujian rumus di atas maka thitung $>$ ttabel yaitu 4,779 > 2.363 dengan derajat error probability 0,01, yang artinya bahwa $\mathrm{H}_{0}$ ditolak dan $\mathrm{H}_{1}$ diterima, artinya model non directive teaching (variabel $\mathrm{X}$ ) memiliki hubungan positif yang signifikan dengan motivasi belajar bahasa Arab siswa (variabel Y).

\section{Pembahasan}

Hasil penelitian ini menunjukan bahwa semakin baik penerapan model non directive teaching akan berdampak baik bagi motivasi belajar bahasa Arab siswa. Hubungan ini dapat menjelaskan bahwa penerapan model non directive teaching mempengaruh motivasi belajar bahasa Arab itu sendiri. Meskipun terdapat hubungan antara model non directive teaching dan motivasi belajar bahasa Arab, namun sumbangan efektif penerapan model non directive teaching terhadap motivasi belajar bahasa Arab siswa sebesar 18,3\%. Sementara sisanya sebesar 81,7\% motivasi belajar bahasa Arab siswa kelas XI SMK Muhammadiyah Prambanan dipengaruhi oleh faktor lain.

Penelitian ini menunjukan bahwa motivasi adalah sesuau yang dinamis dan dipengarui oleh berbagai macam faktor. Faktor tersebut tida hanya bersal dari dari dalam diri individu, melainkan juga dipengaruhi oleh aspek-aspek lingkungan. 
Lebih detailnya Imron (dalam Siregar \& Nara, 2011:53-54) mengemukakan bahwa motivasi belajar dipengaruhi cita-cita dan aspirasi pembelajar; kemampuan pembelajar; kondisi pembelajar; kondisi lingkungan pembelajar; unsur-unsur dinamis belajar dan pembelajaran; dan upaya guru dalam membelajarkan pembelajar. Dalam kaitannya dengan penerapan model pembelajaran, upaya guru sebagai motivator dan fasilitator merupakan faktor yang terpenting dalam pelaksanaannya. Guru memainkan peranan penting dalam mendesain lingkungan belajar (eksternal) dan memaksimalkan potensi dan kemampuan yang ada di dalam diri siswa (internal), sebagaimana hakikat belajar yang dikemukakan oleh Lobart (dalam Georgopoulos \& Vouyoukasi, 2018:128) bahwa belajar adalah respons terhadap stimulus lingkungan dengan motivasi internal individu dan keinginan yang tak terpisahkan yang keduanya saling berkaitan.

Penerapan model non directive teaching merupakan desain lingkungan belajar yang ciptakan guru sesuai dengan kondisi dan kebutuhan pembelajar yang terealisasi melalui non directive kounseling selama pembelajaran, dimana siswa bebas mengungkapkan perasaan, kesulitan, dan tidak ada paksaan dalam pembelajaran. Fokus pembelajajaran adalah guru beserta siswa sama-sama mengatasi permasalahan belajar yang dihadapi, sehingga konsekuensinya pembeajaran tidak cenderung terburu-buru dan mengejar muatan materi yang harus diajarkan melainkan fokus pada sejauh mana kemampuan siswa dan progres yang mereka dapatkan dari pembelajaran.

Pembelajaran yang menjawab kebutuhan siswa akan mempengaruhi perhatiannya dan minatnya sehingga terbentuklah suatu kesan yang baik siswa terhadap pembelajaran yang dialaminya. Terdorongnya siswa melakukan aktivitas pembelajaran dipengaruhi oleh kebutuhannya dengan begitu apabila kebutuhannya telah terpenuhi dalam belajar, hal ini akan mempengaruhi motivasi belajar siswa. Hal ini sesuai apa yang dikemukakan Carl Rogers (dalam Joyce, dkk., 2011:373) bahwa individu memiliki kebutuhan positive regard (perhatian positif) dan teori Maslow mengatakan kebutuhan individu membentuk suatu hierarkis. Kesamaan teori Rogers dan Maslow adalah kebutuhan-kebutuhan tersebut merupakan sifat bawaan, namun dalam pemenuhannya lingkungan ikut perperan penting. Apikasi teori Rogers dan Maslow dalam pembelajaran adalah 
adanya hubungan yang baik, penerimaan dan penghargaan yang terjalin antara guru dan siswa. Oleh karena itu, teori-teori ini mendukung model non directive teaching yang menyatakan bahwa hubungan positif antar sesama manusia memudahkan mereka untuk tumbuh (Joyce, dkk., 2011: 373). Kunci dari non directive teaaching ini adalah penekanan pada elemen emosional, hubungan mitra yang setara antara guru dan siswa, suasana terbuka dalam pengajaran dan evaluasi diri oleh siswa. Tujuan dari hal ini adalah membantu siswa mencapai integrasi diri yang lebih besar. Oleh karena itu, peran guru adalah untuk menciptakan semacam konteks pembelajaran untuk memfasilitasi inspirasi, penilaian, dan evaluasi berbagai proses persepsi baru, yang dapat membantu siswa memahami kebutuhan dan nilai mereka sendiri (Ji-tao, 2019: 686).

Dari pernyataan tersebut dapat dikatakan model pembelajaran yang diterapkan di kelas harus berdasarkan need assesment terhadap siswa atau penilaian berdasarkan kebutuhan siswa sehingga jika kebutuhan siswa terpenuhi dalam belajar maka hal tersebut mempengaruhi motivasinya. Tinggi rendahnya motivasi belajar dipengaruhi oleh kualitas pembelajaran. Demikian halnya dalam penelitian ini, meskipun tingkat penerapan model non directive teaching ini dalam kategori sedang, namun memungkinkan penerapan model ini bisa ditingkatkan, dilakukan perbaikan kualitas dan dievaluasi ke depannya dengan mempertimbangkan berbagai faktor instrinsik dan ekstrinsik pembelajar dalam mendesain lingkungan pembelajaran yang diinginkan.

\section{Simpulan}

Dari hasil penelitian dan pembahasan dapat disimpulkan bahwa terdapat hubungan yang positif dan sangat signifikan antara penerapan model non diretive teaching dengan motivasi belajar bahasa Arab siswa kelas XI di SMK Muhammadiyah Prambanan. Meskipun terdapat hubungan antara keduanya, peran model non directive teaching terhadap motivasi belajar bahasa Arab masih sangat sedikit sebesar $18,3 \%$, sedangkan $71,3 \%$ dipengaruhi oleh variabel lain. Hal ini mengindikasikan bahwa motivasi belajar belajar siswa tidak hanya dipengaruhi oleh satu aspek berupa model pembelajaran saja, melainkan ada 
banyak faktor lain yang mepengaruhinya. Sebagaimana belajar dipengaruhi oleh faktor intrinsik dan ekstrinsik begitu juga motivasi belajar. Dalam kaitannya dengan pembelajaran faktor ekstrinsik berupa peran guru mendesain lingkungan belajar adalah hal yang terpenting dalam tercapainya sebuah pembelajaran yang positif. Oleh karena itu, penerapan model non diretive teaching dalam pembelajaran bahasa Arab perlu ditingkatkan lagi dan dikemas dengan berbagai metode pembelajaran yang mendukung tanpa menghilangkan karakteristik dari non directive teaching dalam model ini, agar tujuan pembelajaran tetap dapat tercapai. Penggunaan metode pembelajaran yang menarik yang tidak mengabaikan aspek emosional diharapkan juga dapat meningkatkan motivasi, perhatian, dan minat siswa terhadap belajar bahasa Arab.

\section{Daftar Pustaka}

Asyrofi, S. (2010). Metodologi Pembelajaran Bahasa Arab. Yogyakarta: Idea Press.

Effendi, M. S., \& Melia, M. (2019). Pengaruh Model Pembelajaran Snowball Throwing terhadap Kemampuan Mengidentifikasi Unsur Intrinsik Teks Drama Siswa Kelas VIII SMP Negeri o Mangunharjo. Silampari Bisa: Jurnal Penelitian Pendidikan Bahasa Indonesia, Daerah, Dan Asing, 2(1), 46. doi:10.31540/silamparibisa.v2i1.326

Georgopoulos, A. \& Vouyoukas, C. (2018). The Effects of the Non-Directive Intervention (NDI) on Preservice Kindergarten Teachers' Self-Esteem, Self-Efficacy and Personal Growth. European Journal of Education Studies, 4 (11), doi: 10.5281/zenodo.1322846

Ghofur, A. (2009). Pengaruh Pembelajaran Non Directive terhadap Keberhasilan Belajar Siswa Kelas VII pada Mata Pelajaran Akidah Akhlak di MTs AlBukhary Angger Sreseh Sampang. Skripsi Fakultas Tarbiyah IAIN Sunan Ampel.

Ji-tao, Z. (2019). Research on the Application of the Non-directive Teaching in College Oral English Instruction in Micro-media Context. Journal of Literature and Art Studies, 9 (7), 686-690 doi: 10.17265/21595836/2019.07.004.

Joyce, B., Weil, M. \& Calhoun, E. (2011). Models of Teaching. Terjemahan Ahmad Fawaid \& Ateilla Mirza. Yogyakarta: Pustaka Pelajar. 
Latipah, E. (2012). Pengantar Psikologi Pendidikan. Yogyakarta: Pedagogia.

Noermanzah, N. (2015). Peran Dosen Bahasa dan Sastra Indonesia dalam Mempertahankan Bahasa Indonesia sebagai Alat Pemersatu Negara Kesatuan Republik Indonesia pada Era Globalisasi. Dalam Prosiding Seminar Nasional Bulan Bahasa 2015. Unit Penerbitan FKIP Universitas Bengkulu, p. 274. http://repository.unib.ac.id/11133/

Noermanzah, N., Abid, S., \& Septaria, S. (2018). Improving the Ability of Writing a Narrative Charge by Using Animated Images Media Student Class V.B SD Negeri 17 Lubuklinggau. BAHTERA: Jurnal Pendidikan Bahasa Dan Sastra, 17(2 Juli), 114-127. doi:10.21009/bahtera.172.9

Ormrod, J. E. (2008). Psikologi Pendidikan Jilid II. Terjemahan Wahyu Indianti, dkk. Jakarta: Erlangga.

Schunk, D. H., Pintrich, P. R., \& Meece, J. L. (2012). Motivasi dalam Pendidikan Teori Penelitian dan Aplikasi. Terjemahan Ellys Tjo. Jakarta: Indeks.

Siregar, E. \& Nara, H. (2011). Teori Belajar dan Pembelajaran. Bogor: Ghalia Indonesia.

Sudijono, A. (2012). Pengantar Statistik Pendidikan. Jakarta: Rajawali Press.

Uno, H. B. (2011). Model Pembelajaran. Jakarta: Bumi Aksara. 